\title{
Surgical treatment of type A acute aortic dissection with cerebral malperfusion: a systematic review
}

\author{
Changtian Wang ${ }^{1}$, LEI ZHANG ${ }^{1}$, tao $\mathrm{li}^{1}$, Zhilong $\mathrm{Xi}^{1}$, Haiwei $\mathrm{Wu}^{1}$, and Demin $\mathrm{Li}^{1}$ \\ ${ }^{1}$ Department of Cardiovascular Surgery Jinling Hospital Nanjing University School \\ Medicine Nanjing P R China
}

November 15, 2021

\begin{abstract}
Purpose: Type A acute aortic dissection (TAAAD) complicated with cerebral malperfusion (CM) is a life-threatening condition associated with high mortality, poor outcomes, and the optimal surgical management remains controversial. The aim of this review was to report the current results of surgical interventions of these patients. Methods: A systematic review was performed using PubMed and MEDLINE search for cases underwent surgical repair for TAAAD with CM. Demographics, neurological symptom, the time from onset of symptoms to operation, operation data, mortality, neurological outcome, and follow-up were reviewed. Results: A total of 363 patients with mean age of $65.7 \pm 13$ years underwent surgical repair for TAAAD with CM were identified in 12 retrospective studies. In-hospital mortality was $20.1 \%$. Mean duration of follow-up was $40.1 \pm$ 37.6 months. The involved supra-aortic branch vessels were RCCA ( $\mathrm{n}=99)$, LCCA $(\mathrm{n}=25)$, B-CCA ( $\mathrm{n}=52)$, CCA ( $\mathrm{n}=131), \mathrm{IA}$ $(n=19)$, and LSA $(n=8)$. Time from onset of neurological symptoms to surgery was 13.3 hours. Antegrade and/or retrograde cerebral perfusion was applied. Postoperatively, improved, unchanged and worsened neurological status was occurred in $54.3 \%$, $27.1 \%$, and $8.5 \%$, respectively in 199 patients. Conclusion: The outcomes of surgical treatment of TAAAD complicated with CM indicate acceptable early mortality and morbidity. It is reasonable to perform lifesaving surgery on these patients. Early central surgical repair and reperfusion of brain may improve the outcomes.
\end{abstract}

\section{INTRODUCTION}

Type A acute aortic dissection (TAAAD) is a life-threatening condition associated with high mortality that requires emergency surgery. Malperfusion of aortic branch vessels is both common and catastrophic, affecting up to one-third of TAAAD cases, and strongly predicting poor outcomes [1]. Cerebral malperfusion (CM) secondary to the occlusion or stenosis of the supra-aortic trunks in TAAAD is an especially feared complication, significantly worsens survival and postoperative quality of life $[2,3]$. The incidence of CM in TAAAD has been reported between $6 \%$ and $26 \%$ in single center studies $[3,4,5,6]$. The mortality associated with the surgical management of TAAAD with CM is high, and the outcomes from previous series have been mixed. To date, the optimal management of TAAAD complicated with CM remains controversial despite numerous advances in the past decades. Coma or stroke complicating TAAAD was once considered to be an absolute contraindication to surgery [7]. Urgent surgical repair in the presence of TAAAD complicated $\mathrm{CM}$ can prevent the early death due to aortic rupture, organ malperfusion, or complicated acute aortic valve insufficiency, but has the risk of hemorrhagic worsening of ischemic infarction during CPB after reperfusion and before $\mathrm{CPB}$ and full anticoagulation. Recently, reports have applied the aggressive surgical approach for patients with TAAAD complicated with CM and shown acceptable outcomes[5, 8, 9].

The aim of the present systematic review is to investigate the current status of the management strategy of TAAAD patients complicated with CM. Understanding these outcomes is helpful for the choice of optimal management of TAAAD patients complicated with CM. 


\section{METHODS}

\section{Literature Search Strategy}

This systematic review was performed and reported in line with the Preferred Reporting Items for Systematic Reviews and Meta-Analyses statement [10]. We searched in PubMed and MEDLINE (https://www.ncbi.nlm.nih.gov/pubmed/) with time point set to end of May 2021 using medical subject headings and text words supplemented by scanning the bibliographies of recovered articles included "type A acute aortic dissection", "acute type A dissection", "cerebral malperfusion", "brain malperfusion", "stroke" and using the Boolean word "AND". Prior to data extraction, all titles, abstracts and full texts were sequentially reviewed following inclusion criteria. Moreover, the reference lists of the selected articles were manually screened and reviewed to identify further relevant citations. Two co-authors (CW and LZ) reviewed and selected relevant articles for inclusion. Differences were resolved in consensus discussions. In order to avoid duplicates, all included studies were independently assessed and critically evaluated. Additional hand searching was undertaken.

\section{Definition}

Evidence for occlusion or severe stenosis (more than 90\%) of the unilateral or bilateral carotid artery as detected by contrast-enhanced CT and carotid duplex scan was defined as cerebral malperfusion. [6] Clinical deficits were associated with preoperative symptomatic motor or sensory deficits, including transient neurological deficit, syncope, stroke, coma, altered consciousness, and hemiplegia.

\section{Inclusion criteria}

The predefined inclusion criteria were cases underwent surgical repair for TAAAD complicated with CM confirmed by contrast-enhanced CT or carotid duplex scan prior operation. The reports in which we could extract the exact number of cases with TAAAD complicated with CM from the total amount of reported cases were included. It was essential that included studies should document the data on operation and outcomes, including mortality, neurological outcomes and follow-up. Only the most recent report from each centre was accepted in order to avoid duplicate data. Language was limited to articles written in English.

\section{Exclusion criteria}

The articles in which CM was confirmed during or after surgical repair were excluded. Papers in which data could not be precisely extracted were also excluded. The reports which could not be reviewed by fulltext were not included. Case reports, correspondence letters, expert opinions and reviews were not included, as well.

\section{Data extraction and risk of bias assessment}

We collected data on study design, number of patients, age, gender, preoperative neurological symptom including syncope, stroke, hemiplegia, comatose state, Glasgow Coma Scale (GCS), and National Institutes of Health stroke scale (NIHSS), the time from onset of symptoms to operation, the operation data including cannulation, procedure (hemiarch replacement, HAR; partial arch replacement, PAR; total arch replacement, TAR), hypothermic cardiac arrest (HCA) time, temperature during HCA, cerebral perfusion (antegrade cerebral perfusion, ACP; retrograde cerebral perfusion, $\mathrm{RCP}$ ), cross-clamp time (CCT), and cardiopulmonary bypass $(\mathrm{CPB})$ time, the mortality rate, the neurological outcomes and follow-up.

The risk of bias was assessed at the study level using the Cochrane's Collaboration Risk of Bias Tool [11]. Through six domains, this tool evaluates the risk of bias and categorizes each study as high-risk, low-risk, or unclear-risk of bias.

\section{Statistical analysis}

Data collected were organized in an Apple Numbers spreadsheet version 6.6.2. A descriptive statistics was used to describe the demographic data with continuous variables reported as mean \pm standard deviation (SD) and dichotomous variables expressed as numbers with percentage. 


\section{RESULTS}

The literature search yielded 367 publications in PubMed and MEDLINE databases. We screened them by title/abstract and full text. As a consequence of this analysis, 12 publications focusing on the treatment of TAAAD complicated with CM were included in the study, spanning a period of time ranging from 2005 to 2021 (Figure 1). All included reports were retrospective studies.

\section{Patient characteristics}

A total of 2342 patients underwent surgical repair for TAAAD. Of these, 363 (15.5\%) presented with CM. $100(27.5 \%)$ were females, and the mean age was $65.7 \pm 13$ years $[3,5,8,9,12-19]$. All patients were confirmed TAAAD with CM by clinical presentation and contrast-enhanced CT or carotid duplex scan, and received surgical repair for TAAAD. No studies reported the preoperative EuroSCORE II or the American Society of Anesthesiologists score.

\section{In -hospital mortality, cause of death and follow-up}

In-hospital mortality was $20.1 \%(\mathrm{n}=73)$, ranging from 0 to $50 \%$. 10 studies $(\mathrm{n}=222)$ documented the causes of death: severe brain damage or neurological $(\mathrm{n}=28 / 222)$, multiorgan failure $(\mathrm{n}=1 / 222)$, aortic rupture $(n=1 / 222)$, acute myocardial infarction $(n=1 / 222)$, and small bowel necrosis $(n=1 / 222)$. The median time from onset of neurological symptoms to surgery was $13.3+-31.3$ (range, $0.6-240$ ) hours. Of these, 214 cases were within $10 \mathrm{~h}$, and 149 cases were $>10 \mathrm{~h}$. The mortality was $16.7 \%$ and $23.4 \%$ respectively. Mean duration of follow-up was $40.1+-37.6$ months in 10 papers for 302 patients. Of these studies, the five-year survival was $65.3 \%+-11 \%$ in 5 papers, and the 10 -year survival was $60.5+-23.4 \%$ and $59 \%$ +$9 \%$ respectively in two studies.

\section{Preoperative neurological presentation and postoperative neurological outcomes}

The documented preoperative neurological presentation was in $73.3 \%$ of patients. The most presentation was stroke or cerebrovascular accident $(\mathrm{n}=188)$ and coma or altered consciousness $(\mathrm{n}=124)$. Syncope presented in 54 patients,and TIA presented in 16. The rare presentation seizure was in 3 patients. The preoperative GCS was reported in 3 studies, but the definition is varied. The preoperative NIHSS score was 18.2 +- 13.3 in 3 papers. One paper provided a Japan Coma Scale [2 $(\mathrm{n}=6), 20(\mathrm{n}=2), 200(\mathrm{n}=1)]$.

In nine studies, the postoperative neurological outcome was documented according to the recovery of neurologic status including 199 patients, completely recovered or improved in 108 (54.3\%) patients, remained the same or on change in $54(27.1 \%)$ patients, and worsened in $17(8.5 \%)$ patients. Two reports only recorded the new postoperative neruological deficits in 30 patients( $46.2 \%)$. The new-onset postoperative neurological dysfunction was in 50 patients. In one paper, the post-CVA was 11 (11.1\%), and the post-coma was 9 (9.1\%).

\section{Operative details}

The involved supra-aortic branch vessels were shown in Figure 2. All patients underwent median sternotomy with total cardiopulmonary bypass and surgical repair of ascending aorta with or without proximal aortic root repair. The arch repair depended on the tear location. $118(38.4 \%, 118 / 307)$ patients underwent hemiarch replacement (HAR), $86(28 \%, 86 / 307)$ underwent total arch replacement (TAR), and 50(16.3\% 50/307) underwent partial arch replacement (PAR). Two studies reported the additional procedure extra-anatomic aorto-carotid bypass for impaired CCA $(\mathrm{n}=32)$. The femoral or right axillary arteries or both were the most frequent choices for arterial cannulation. The additional arterial inflow included ascending aorta (n $=22)$, carotid artery $(\mathrm{n}=11)$, innominate artery $(\mathrm{n}=6)$, cardiac apex $(\mathrm{n}=1)$. Antegrade (unilateral or bilateral) and/or retrograde cerebral perfusion were (was) recorded as brain protection during surgery in ten reports including 214 patients. Of these patients, 152 (71\%) underwent ACP, 67 (31.3\%) underwent RCP. The mean target core temperature during hypothermic cardiac arrest was $22.7+-3.3$ (15 - 29.3), and the mean hypothermic cardiac arrest time was $41.9+-16.7$ (18-77) minutes in 91 patients. The mean crossclamp time and CPB time was $131+-45.4$ and $213.9+-73.8$ minutes respectively. The details of operative procedures were summarized in table 3 . 


\section{DISCUSSION}

In the study from the International Registry of Acute Aortic Dissection (IRAAD) reported by Sultan I et al [6], which represented the largest study to date assessing the impact of $\mathrm{CM}$ at the time of presentation for patients with TAAAD, $15.1 \%$ of patients presented with CM. Our study also reveals that the incidence of CM in TAAAD is $15.9 \%$, ranged from $6.5 \%$ to $26.1 \%$. Despite the surgical techniques, the anesthesiology and perioperative management have greatly improved over the last years, and the mortality rate has improved significantly in the surgical treatment for TAAAD patients with $\mathrm{CM}$, the mortality remains high. A report by Fann JI, et al in 1989 demonstrated that the surgical results of such patients showed a high mortality rate of $57 \%[20]$. In 2007, the report from University of Pennsylvania by Geirsson A, et al[21] showed that the mortality rate was $50 \%$ in surgical repair for TAAAD with CM patients. A report from Japan by Okita Y, et al in 2021 showed that the mortality rate is $28 \%$ [12]. From our investigation, the mean in-hospital mortality is $20.1 \%$. However, the outcomes is variable. In a few studies, the mortality was 0 and the long time survival was acceptable. Although the number of cases in these studies was not so enough, the results was encouraging in this critically ill cohort of patients. TAAAD patients with CM should not preclude surgical candidacy.

In the case of acute ischemic cerebrovascular pathology, the interval from onset of neurological symptoms to return of cerebral blood flow is key factor in determining the severity and recovery of cerebral injury. The 2015 guidelines of the Healthcare Professionals from the American Heart Association/American Stroke Association reported the efficacy of endovascular treatment within 8 hours of symptom onset for patients with acute ischemic stroke [22]. Data from our review show that the mean time from presentation of neurological symptoms to surgical intervention is 13.3 hours. Multiple studies shown patients who initially underwent early surgical repair or reperfusion of brain had good outcomes $[5,8,9,18,23,24]$. The mortality in the group which surgery underwent within 10 hours was significantly lower than that of patients over 10 hours. Tsukube et al. [18] performed immediate surgery within 5 h for TAAAD patients with coma, which resulted in full recovery of consciousness in $86 \%$ and hospital mortality of $14 \%$. Estrera et al [9] reported the operative results of 16 patients with TAAAD complicated by preoperative stroke. The median time from onset of stroke to surgery was 9 hours, and $80 \%$ of patients who underwent surgical repair within 10 hours had improvement in neurologic status, whereas none improved if operated on beyond 10 hours. Sasaki $\mathrm{H}$ et al [8] reported that hemiplegia and hemiparesis improved significantly after immediate aortic repair in which the time from onset of symptoms to operating room was $7.2+-2.4 \mathrm{~h}$, with hospital mortality of $0 \%$ and overall survival at 24 months after operation of $100 \%$. Morimoto et al [5] also reported that 9.1 hours was an optimal cutoff value for predicting lack of neurologic improvement-if surgery was performed within 9.1 hours, $88 \%$ improved neurologically, with dramatically improved 5-year survival ( $84 \%$ vs. $33 \%$ ). Those present researches indicate that early surgical repair within 10 hours may improve the outcomes. However, multicenter controlled clinical trials with large samples are needed.

Cerebral malperfusion time plays a role in determining outcomes in TAAAD patients, and expeditious revascularization was crucial in the management strategy of TAAAD with CM. Early reperfusion and extraanatomic revascularization may reduce the risk of neurological complications. A number of institutions have adopted strategies to minimize cerebral malperfusion time and reperfuse the cerebral blood flow sooner, including extra-anatomic revascularization $[8,14,16]$, direct carotid artery cannulation $[12,13,25,26]$, or percutaneous endovascular carotid artery stenting [25]. Immediate central aortic repair and primary entry tear resection is the most widely practiced early reperfusion strategy, wherein the goals are to expand the true lumen by redirecting flow into it and to decompress the false lumen by resecting the entry tear, and has been shown to improve outcomes in patients with malperfusion [9, 27, 28]. Arterial cannulation sites are determined according to a patient's status, preoperative involved supra-aortic branch vessels and the preference of the surgeon. The right axillary artery is the most frequent choice because it will allow for uninterrupted ACP during arch reconstruction. RCP, another bran protection strategy, is also performed in many centers, which can flush out air and atheromatous debris within the arch vessels [5, 6, 9, 12, 19,25,29,30]. The extent of aortic replacement is determined on the position of the primary entry, and ascending aorta combined with hemi-arch replacement with or without root replacement or repair is performed in most 
patients. It is necessary to investigate the correlation between outcomes and operation strategies, such as the extent of aortic replacement and selective cerebral perfusion, in TAAAD with CM patients.

Coma is the common presentation following TAAAD complicated with CM, and its definition is varied among studies. There has controversial with regards to the surgical management required cardiopulmonary bypass, full anticoagulation with hypothermic circulatory arrest for a patient in coma. The threat of use of highdose heparin, hemorrhagic conversion of the ischemic infarction, cerebral reperfusion leading to worsening of neurologic outcome exists. For this reason, Fukuda et al. advocated intentional delay of surgical repair [31]. Fukuhara S and colleagues [25] found that all patients developed severe cerebral edema and herniation syndrome died regardless of the surgical management. Caution is necessary because the differentiation of coma is vitally important, and is difficult also. Cranial computed tomographic scanning often does not identify early acute ischemic infarction, however, is the best means to rule out acute bleeding [32]. Patients with the evidence of intracranial hemorrhage have been an absolute contraindication to immediate surgical repair.

Several limitations to our study exist. This is a retrospective systematic review of published reports on surgical treatment of TAAAD complicated with CM. The inherent limitations of a retrospective study and review should be acknowledged. There could be a risk of publication bias because several data are missing during the investigation. There is a degree of heterogeneity in the pathology, the operative and cerebral protection strategy for TAAAD patients with CM among different institutions. In addition, there is a lack of standardization in evaluation of the neurological presentations and outcomes. Lastly, the prognosis of TAAAD is determined on many factors, and malperfusion of other organ systems is common in TAAAD patients with CM and potential significant bias by this fact may exist. Further investigation and clinical research using standardized methodology is highly warranted to validate our results.

\section{CONCLUSION}

The outcomes of surgical treatment of TAAAD with CM have been improved, and indicate acceptable early mortality and morbidity in this critically ill cohort of patients. It is reasonable to perform lifesaving surgery on patients who present with TAAAD complicated by CM. Early central surgical repair and reperfusion of brain may improve the outcomes. Indeed, clinical trials with large samples are needed.

Funding: This research did not receive any specific grant from funding agencies in the public, commercial, or not-for-profit sectors.

Conflicting of interest: The authors declare that there are no conflicts of interest.

Acknowledgment: No.

\section{Author contributions:}

Changtian Wang : Conceptualization; Data curation; Formal analysis; Methodology; Validation; Writing - original draft, review \& editing. Lei Zhang : Data curation; Investigation; Methodology; Writing - original draft. Tao Li, Zhilong Xi and Haiwei Wu : Data curation; Formal analysis; Validation. Demin Li : Supervision; Validation; Writing - review.

\section{Figure Legend}

\section{Figure 1.}

Flow diagram to illustrate identification, selection and exclusion of articles used for the review.

\section{Figure 2.}

The involved supra-aortic branch vessels.

\section{Tables}

Table 1. Case series summary of surgical treatment of TAAAD complicated with CM. 


\begin{tabular}{|c|c|c|c|c|c|c|c|c|}
\hline Author & $\begin{array}{l}\text { Article } \\
\text { types }\end{array}$ & Year & $\begin{array}{l}\mathrm{N} \text { of } \\
\text { patients }\end{array}$ & $\begin{array}{l}\text { Incidence } \\
(\%)\end{array}$ & $\begin{array}{l}\text { Age } \\
\text { (years) }\end{array}$ & $\operatorname{Sex}(F)$ & $\begin{array}{l}\text { In- } \\
\text { hospital } \\
\text { mortality } \\
(\%)\end{array}$ & $\begin{array}{l}\text { Causes } \\
\text { of death }\end{array}$ \\
\hline $\begin{array}{l}\text { Okita Y et } \\
\text { al [12] }\end{array}$ & $\mathrm{RS}$ & 2021 & 50 & 13.1 & $68.1 \pm 9.2$ & NA & $14(28 \%)$ & stroke 8 \\
\hline $\begin{array}{l}\text { Sugiyama } \\
\text { K et al } \\
{[13]}\end{array}$ & $\mathrm{RS}$ & 2021 & 19 & 21 & $\begin{array}{l}69 \\
(39-84)\end{array}$ & 2 & $\begin{array}{l}2 \\
(10.5 \%)\end{array}$ & $\begin{array}{l}\text { extensive } \\
\text { cere- } \\
\text { bral } \\
\text { infarction }\end{array}$ \\
\hline $\begin{array}{l}\text { Gomibuchi } \\
\mathrm{T} \text { et al } \\
{[14]}\end{array}$ & $\mathrm{RS}$ & 2021 & 42 & 21.3 & $\begin{array}{l}64.9 \pm \\
11.1\end{array}$ & 22 & $\begin{array}{l}2 \\
(4.8 \%)\end{array}$ & NA \\
\hline $\begin{array}{l}\text { Sasaki } \\
\mathrm{H} \text { et al } \\
{[8]}\end{array}$ & $\mathrm{RS}$ & 2020 & 9 & 7.1 & $66.2 \pm 12.9$ & 8 & 0 & 0 \\
\hline $\begin{array}{l}\text { Shimura } \\
\text { S et al } \\
{[15]}\end{array}$ & $\mathrm{RS}$ & 2020 & 16 & 7.7 & $\begin{array}{l}63 \\
(32-83)\end{array}$ & 8 & $\begin{array}{l}1 \\
(6.3 \%)\end{array}$ & $\begin{array}{l}\text { severe } \\
\text { cere- } \\
\text { bral } \\
\text { edema }\end{array}$ \\
\hline $\begin{array}{l}\text { Luehr } \\
\text { M et } \\
\text { al }[16]\end{array}$ & $\mathrm{RS}$ & 2016 & 23 & 6.5 & $\begin{array}{l}66.3(55.2- \\
69.9)\end{array}$ & 5 & $\begin{array}{l}3 \\
(13.0 \%)\end{array}$ & $\begin{array}{l}\text { cerebral } \\
\text { haem- } \\
\text { orrhag } \\
2, \\
\text { MOF } 1\end{array}$ \\
\hline $\begin{array}{l}\text { Di } \\
\text { Eusanio M } \\
\text { et al [3] }\end{array}$ & $\mathrm{RS}$ & 2013 & 99 & 7.5 & $\begin{array}{l}63.1 \pm 13.7 \\
62.8 \pm 12.2\end{array}$ & NA & $33(33.3 \%)$ & $\mathrm{NA}$ \\
\hline $\begin{array}{l}\text { Morimoto } \\
\mathrm{N} \text { et al }[5]\end{array}$ & $\mathrm{RS}$ & 2011 & 41 & 26.1 & $\begin{array}{l}67.3 \pm 10.0 \\
69.7 \pm 11.5\end{array}$ & 16 & $6(14.6 \%)$ & $\begin{array}{l}\text { large } \\
\text { hemi- } \\
\text { spheric } \\
\text { infarction, }\end{array}$ \\
\hline $\begin{array}{l}\text { Nakamura } \\
\mathrm{Y}[17]\end{array}$ & $\mathrm{RS}$ & 2011 & 10 & 22.4 & $\begin{array}{l}69 \pm 9 \\
(57-84)\end{array}$ & 5 & 0 & 0 \\
\hline
\end{tabular}




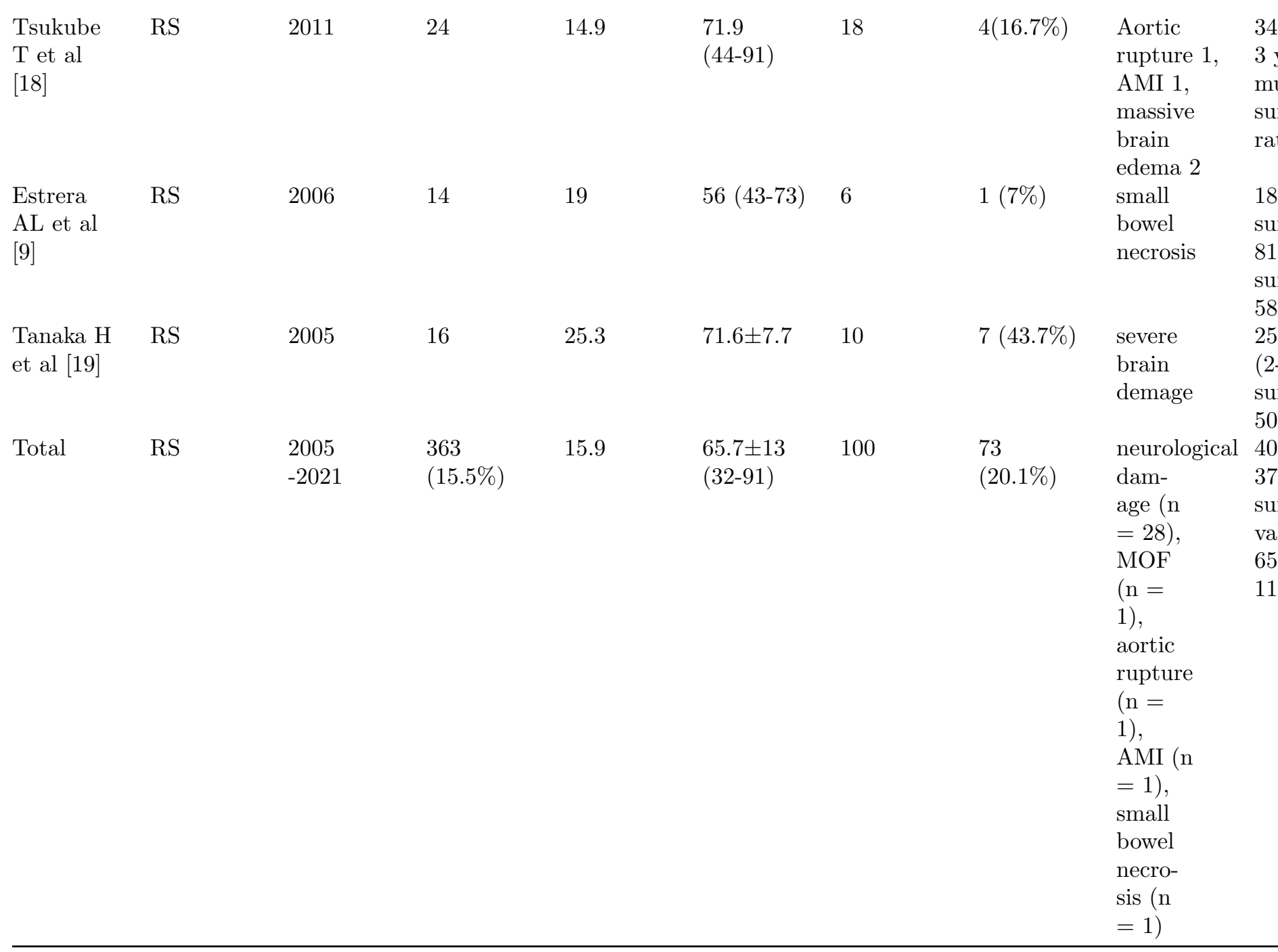

Notes: $\mathrm{AMI}=$ acute myocardial infarction; $\mathrm{CM}=$ cerebral malperfusion; $\mathrm{mo}=$ month; $\mathrm{MOF}=$ multiorgan failure; $\mathrm{NA}=$ not available; $\mathrm{TAAAD}=$ Type $\mathrm{A}$ acute aortic dissection.

Table 2. The preoperative neurological presentation and outcomes in TAAAD complicated with CM underwent surgical treatment.

\begin{tabular}{|c|c|c|c|c|c|}
\hline Author & $\mathbf{N}$ of patients & PreNS & $\begin{array}{l}\text { Neurological } \\
\text { state } \\
\text { (GCS/NIHSS) }\end{array}$ & $\begin{array}{l}\text { Involved } \\
\text { SABV }\end{array}$ & $\begin{array}{l}\text { Neurological } \\
\text { outcomes }\end{array}$ \\
\hline $\begin{array}{l}\text { Okita Y et al } \\
{[12]}\end{array}$ & 50 & $\begin{array}{l}\text { TIA } 10 \\
\text { coma/altered } \\
\text { consciousness } \\
12 \text { hemiplegia } \\
28\end{array}$ & $\begin{array}{l}\text { GCS: severe } \\
(3-8) 12 \\
\text { moderate } \\
(9-12) 18 \text { mild } \\
(11-13) 20\end{array}$ & $\begin{array}{l}\text { RCCA } 34 \\
\text { LCCA } 2 \\
\text { B-CCA } 14\end{array}$ & $\begin{array}{l}\text { improved } 14 \\
\text { no change } 16 \\
\text { worsened } 3\end{array}$ \\
\hline $\begin{array}{l}\text { Sugiyama K et } \\
\text { al [13] }\end{array}$ & 19 & $\begin{array}{l}\text { neurological } \\
\text { deficit } 8\end{array}$ & NA & $\mathrm{CCA}$ & $\begin{array}{l}\text { improved } 3 \text { no } \\
\text { change } 11 \\
\text { worsened } 5\end{array}$ \\
\hline
\end{tabular}




\begin{tabular}{|c|c|c|c|c|c|}
\hline $\begin{array}{l}\text { Gomibuchi } \mathrm{T} \\
\text { et al [14] }\end{array}$ & 42 & $\begin{array}{l}\text { persistent } \\
\text { neurological } \\
\text { deficit } 8 \\
\text { transient } 5 \text { no } \\
29\end{array}$ & NA & $\begin{array}{l}\text { RCCA } 28 \\
\text { LCCA } 5 \\
\text { B-CCA } 9\end{array}$ & NewPOND 16 \\
\hline Sasaki $\mathrm{H}$ et al [8] & 9 & $\begin{array}{l}\text { seizure } 2 \\
\text { hemiplegia } 4\end{array}$ & $\begin{array}{l}\text { Japan Coma } \\
\text { Scale 2(6), 20(2), } \\
200(1)\end{array}$ & IA or RCCA & $\begin{array}{l}\text { improved } 9 \text { no } \\
\text { change } 0 \\
\text { worsened } 0\end{array}$ \\
\hline $\begin{array}{l}\text { Shimura } S \text { et al } \\
{[15]}\end{array}$ & 16 & $\begin{array}{l}\text { coma } 10 \\
\text { hemiplegia } 6\end{array}$ & GCS: [?]8 (10) & $\begin{array}{l}\text { IA } 16, \text { RCCA } 12 \\
\text { LCCA } 7 \text { LSA } 8\end{array}$ & $\begin{array}{l}\text { improved } 14 \text { no } \\
\text { change } 0 \\
\text { worsened } 2\end{array}$ \\
\hline $\begin{array}{l}\text { Luehr M et al } \\
{[16]}\end{array}$ & 23 & $\begin{array}{l}\text { syncope } 7 \text {, } \\
\text { seizure } 1 \text {, } \\
\text { vertigo } 5 \text {, } \\
\text { photopsia } 1 \text {, } \\
\text { confusion } 7\end{array}$ & NA & $\begin{array}{l}\text { B-CCA } 1 \\
\text { LCCA } 10 \\
\text { RCCA } 12\end{array}$ & NewPOND 14 \\
\hline $\begin{array}{l}\text { Di Eusanio M et } \\
\text { al[3] }\end{array}$ & 99 & $\begin{array}{l}\text { syncope } 61 \text {, CVA } \\
87 \text {, coma } 54\end{array}$ & NA & NA & $\begin{array}{l}\text { post-CVA } 11 \\
\text { post-coma } 9\end{array}$ \\
\hline $\begin{array}{l}\text { Morimoto } \mathrm{N} \text { et } \\
\text { al [5] }\end{array}$ & 41 & $\begin{array}{l}\text { coma } 7, \text { stupor } \\
13 \text {, hemiplegia } \\
19 \text {, hemianopsia } \\
2\end{array}$ & $\begin{array}{l}\text { NIHSS:10.7 } \pm 7.9 \\
\text { (median } 8.0 \text { ) }\end{array}$ & $\mathrm{CCA}$ & $\begin{array}{l}\text { improved } 26 \text { no } \\
\text { change } 15 \\
\text { worsened? }\end{array}$ \\
\hline $\begin{array}{l}\text { Nakamura Y et } \\
\text { al [17] }\end{array}$ & 10 & $\begin{array}{l}\text { hemiplegia } 9 \text {, } \\
\text { CVA } 6 \text {, motor } \\
\text { aphasia } 1\end{array}$ & $\begin{array}{l}\text { NIHSS: } 5.5 \pm 2.9 \\
(4-13)\end{array}$ & IA 3 B-CCA 7 & $\begin{array}{l}\text { improved } 10 \text { no } \\
\text { change } 0 \\
\text { worsened } 0\end{array}$ \\
\hline $\begin{array}{l}\text { Tsukube } T \text { et al } \\
{[18]}\end{array}$ & 24 & coma 27 & $\begin{array}{l}\text { GCS } 6.5(3-10) \\
\text { NIHSS } 31.4 \pm 6.6\end{array}$ & $\begin{array}{l}\text { unilateral } 12 \\
\text { bilateral } 10\end{array}$ & $\begin{array}{l}\text { improved } 19 \text { no } \\
\text { change? } \\
\text { worsened } 1\end{array}$ \\
\hline $\begin{array}{l}\text { Estrera AL et } \\
\text { al }[9]\end{array}$ & 14 & $\begin{array}{l}\text { CVA } 16 \text { coma } \\
1\end{array}$ & NIHSS: 12.9 & NA & $\begin{array}{l}\text { improved } 8 \text { no } \\
\text { change } 6 \\
\text { worsened } 1(< \\
10 \text { hs, } 80 \% \\
\text { improved }> \\
\text { 10hs, none } \\
\text { improved) }\end{array}$ \\
\hline $\begin{array}{l}\text { Tanaka } \mathrm{H} \text { et al } \\
{[19]}\end{array}$ & 16 & $\begin{array}{l}\text { hemiplegia } 8 \text {, } \\
\text { TIA } 6 \text {, coma } 5 \text {, } \\
\text { drawsy } 3 \text {, deficit } \\
\text { of consciousness } \\
2\end{array}$ & $\begin{array}{l}\text { GCS: } 9.5 \pm 5.2 \\
(16,5 ; 9-11,4 ; \\
<6,7)\end{array}$ & $\begin{array}{l}\text { RCCA } 4 \text { LCCA } \\
1 \text { B-CCA } 11\end{array}$ & $\begin{array}{l}\text { improved } 5 \text { no } \\
\text { change } 6 \\
\text { worsened } 5\end{array}$ \\
\hline Total & 363 & & $\begin{array}{l}\text { GCS (4 papers) } \\
\text { definition is } \\
\text { varied. [2]NIHSS } \\
\text { score } 18.2 \pm 13.3 \\
\text { (4 papers) }\end{array}$ & $\begin{array}{l}\text { RCCA }(n=99), \\
\text { LCCA }(n=25), \\
\text { B-CCA }(n=52), \\
\text { CCA }(n=131), \\
\text { IA }(n=19), \text { LSA } \\
(n=8)\end{array}$ & $\begin{array}{l}\text { improved } 108 \text { no } \\
\text { change } 54 \\
\text { worsened } 17 \text { (of } \\
199 \text { patients) }\end{array}$ \\
\hline
\end{tabular}

Notes: $\mathrm{B}-\mathrm{CCA}=$ bilateral common carotid artery; $\mathrm{CCA}=$ common carotid artery; $\mathrm{CM}=$ cerebral malperfusion; $\mathrm{CVA}=$ cerebrovascular accident; GCS = Glasgow Coma Scale; IA = innominate artery; ICA = internal carotid artery; LCCA = left common carotid artery; LSA = left subclavian artery; NA = not available; NIHSS $=$ National Institutes of Health stroke scale; PreNS = preoperative neurological symptom; RCCA 
$=$ right common carotid artery; $\mathrm{SABV}=$ supra-aortic branch vessels; TAAAD $=$ Type $\mathrm{A}$ acute aortic dissection.

Table 3. Summary of details of procedures in the treatment of TAAAD complicated with CM.

\begin{tabular}{|c|c|c|c|c|c|c|c|c|}
\hline Author & $\begin{array}{l}\mathrm{N} \text { of } \\
\text { patients }\end{array}$ & $\begin{array}{l}\text { Time } \\
\text { OSTOR } \\
\text { (hours) }\end{array}$ & procedure & $\begin{array}{l}\text { cannulation } \\
\text { (Arterial } \\
\text { inflow) }\end{array}$ & $\begin{array}{l}\mathrm{CP} \\
(\mathrm{ACP} / \mathrm{RCP})\end{array}$ & $\begin{array}{l}\text { T during } \\
\text { CA () }\end{array}$ & $\mathrm{HCA}(\min )$ & $\mathrm{CCT}(\min )$ \\
\hline $\begin{array}{l}\text { Okita Y et } \\
\text { al [12] }\end{array}$ & 50 & $6.0 \pm 32.6$ & $\begin{array}{l}\text { HAR } 32 \\
\text { PAR } 2 \\
\text { TAR } 18\end{array}$ & $\begin{array}{l}\text { FA } 32, \text { Ax } \\
9, \text { AA } 7 \\
\text { FA }+ \text { Ax } 3\end{array}$ & NA & NA & NA & NA \\
\hline $\begin{array}{l}\text { Sugiyama } \\
\mathrm{K} \text { et al } \\
{[13]}\end{array}$ & 19 & $\begin{array}{l}5.7 \\
(3.5-8.4) \\
7.1 \\
(2.9-9.9)\end{array}$ & $\begin{array}{l}\text { HAR } 3 \\
\text { PAR } 5 \\
\text { TAR } 11\end{array}$ & $\mathrm{Ax}+\mathrm{FA}$ & ACP 19 & $\begin{array}{l}23.8 \\
(21.1- \\
24.7) 23.5 \\
(21.8- \\
24.5)\end{array}$ & $\begin{array}{l}58(33-77) \\
49(38-65)\end{array}$ & $\begin{array}{l}133 \\
(104-199) \\
152 \\
(100-236)\end{array}$ \\
\hline $\begin{array}{l}\text { Gomibuchi } \\
\text { T et al } \\
{[14]}\end{array}$ & 42 & $\begin{array}{l}8.8 \pm \\
8.28 .0 \\
\pm 2.9\end{array}$ & NA & $\mathrm{Ax}+\mathrm{FA}$ & $\begin{array}{l}\mathrm{ACP} \\
42\end{array}$ & $\mathrm{NA}$ & NA & NA \\
\hline $\begin{array}{l}\text { Sasaki H } \\
\text { et al [8] }\end{array}$ & 9 & $7.2 \pm 2.4$ & $\begin{array}{l}\text { HAR } 4 \\
\text { PAR } 0 \\
\text { TAR } 5\end{array}$ & $\begin{array}{l}\text { IA } 5, \\
\text { RCCA } 4 \\
\text { Ax+FA }\end{array}$ & ACP 9 & 25 & $57 \pm 15 \mathrm{~min}$ & $118 \pm 24$ \\
\hline $\begin{array}{l}\text { Shimura S } \\
\text { et al [15] }\end{array}$ & 16 & $\begin{array}{l}5.5 \\
(2.9-9.4)\end{array}$ & $\begin{array}{l}\text { HAR } 0 \\
\text { PAR } 0 \\
\text { TAR } 6\end{array}$ & $\begin{array}{l}\mathrm{AA} 14, \\
\mathrm{AA}+\mathrm{FA} 2\end{array}$ & RCP 16 & 17.5 & $33(25-45)$ & NA \\
\hline $\begin{array}{l}\text { Luehr } \\
\text { M et } \\
\text { al[16] }\end{array}$ & 23 & $\begin{array}{l}7.0 \\
(4.9- \\
12.1)\end{array}$ & $\begin{array}{l}\text { HAR } \\
14 \\
\text { PAR } 0 \\
\text { TAR } 9\end{array}$ & $\begin{array}{l}\text { Ax } 15, \\
\text { FA } 7, \\
\text { IA 1, } \\
\text { AA } 1, \\
\text { Car- } \\
\text { diac } \\
\text { apex1 }\end{array}$ & $\begin{array}{l}\mathrm{ACP} \\
23\end{array}$ & $\begin{array}{l}26.0 \pm \\
3.3\end{array}$ & $\begin{array}{l}33.5 \pm \\
14.4\end{array}$ & $\begin{array}{l}111.4 \\
\pm 36.2\end{array}$ \\
\hline $\begin{array}{l}\text { Di Eu- } \\
\text { sanio } \\
\text { M et al } \\
{[3]}\end{array}$ & 99 & $\begin{array}{l}12.3 \\
(6.6- \\
56.1) \\
13.8 \\
(6.3- \\
24.0)\end{array}$ & $\begin{array}{l}\text { TAR } \\
12 \\
\text { PAR } \\
42 \\
\text { TAR } 0\end{array}$ & NA & NA & NA & NA & NA \\
\hline $\begin{array}{l}\text { Morimoto } \\
\mathrm{N} \text { et al } \\
{[5]}\end{array}$ & 41 & $\begin{array}{l}21.7 \pm 40.5 \\
\text { (medi- } \\
\text { an } \\
6.5)\end{array}$ & $\begin{array}{l}\text { HAR } \\
15 \\
\text { PAR } 0 \\
\text { TAR } \\
26\end{array}$ & $\mathrm{Ax}, \mathrm{FA}$ & $\begin{array}{l}\text { ACP } \\
19 \\
\text { RCP } \\
22\end{array}$ & $\begin{array}{l}23.0 \pm \\
2.3 \\
22.0 \pm 3.8\end{array}$ & NA & $\begin{array}{l}119.2 \pm 51.4 \\
123.0 \pm 62.0\end{array}$ \\
\hline $\begin{array}{l}\text { Nakamura } \\
\mathrm{Y}[17]\end{array}$ & 10 & $9.2 \pm 8.7$ & $\begin{array}{l}\text { HAR } 9 \\
\text { PAR } 0 \\
\text { TAR } 1\end{array}$ & NA & $\begin{array}{l}\text { ACP } 9 \\
\text { RCP } 1\end{array}$ & $25 \pm 1$ & $31 \pm 9$ & NA \\
\hline $\begin{array}{l}\text { Tsukube } \\
\mathrm{T} \text { et al } \\
{[18]}\end{array}$ & 24 & $\begin{array}{l}3.4 \pm 1 \\
(21) \\
35.5 \pm 8.4(3)\end{array}$ & $\begin{array}{l}\text { HAR } \\
19 \\
\text { PAR } 0 \\
\text { TAR } 5\end{array}$ & $\begin{array}{l}\text { FA } 23, \\
\text { FA+ } \\
\text { Ax } 1\end{array}$ & $\begin{array}{l}\mathrm{ACP} \\
27\end{array}$ & 18 & NA & NA \\
\hline
\end{tabular}




\begin{tabular}{|c|c|c|c|c|c|c|c|c|}
\hline $\begin{array}{l}\text { Estrera } \\
\text { AL et } \\
\text { al [9] }\end{array}$ & 14 & $\begin{array}{l}6.1 \pm 2.9 \\
(10) \\
162 \pm 90.6(4)\end{array}$ & $\begin{array}{l}\text { HAR ? } \\
\text { PAR 0 } \\
\text { TAR } 0\end{array}$ & $\mathrm{FA}, \mathrm{Ax}$ & $\begin{array}{l}\mathrm{RCP} \\
16\end{array}$ & $15-20$ & $\begin{array}{l}28 \\
(18-46)\end{array}$ & NA \\
\hline $\begin{array}{l}\text { Tanaka } \\
\mathrm{H} \text { et al } \\
{[19]}\end{array}$ & 16 & $\begin{array}{l}7.8 \pm 6.6 \\
(3-30) \\
{[7,4} \\
\text { days }]\end{array}$ & $\begin{array}{l}\text { HAR } \\
10 \\
\text { PAR } 1 \\
\text { TAR } 5\end{array}$ & $\begin{array}{l}\text { FA 10, } \\
\text { FA+Ax } \\
6\end{array}$ & $\begin{array}{l}\text { RCP } \\
12 \\
\mathrm{ACP} 4\end{array}$ & 20 & NA & NA \\
\hline Total & 363 & $\begin{array}{l}13.3 \pm \\
31.3\end{array}$ & $\begin{array}{l}\text { HAR } \\
=118 \\
\text { PAR }= \\
50 \\
\text { TAR }= \\
86\end{array}$ & $\begin{array}{l}\text { AA } 22, \\
\text { apex } 1, \\
\text { carotid } \\
11, \text { IA } \\
6\end{array}$ & $\begin{array}{l}\mathrm{ACP}= \\
152 \\
\mathrm{RCP}= \\
67\end{array}$ & $\begin{array}{l}22.7 \pm \\
3.3 \\
(15- \\
29.3)\end{array}$ & $\begin{array}{l}41.9 \pm \\
16.7 \\
(18-77)\end{array}$ & $\begin{array}{l}131 \pm \\
45.4 \\
(61- \\
236)\end{array}$ \\
\hline
\end{tabular}

Notes: $\mathrm{AA}=$ ascending aorta; $\mathrm{ACP}=$ antegrade cerebral perfusion; $\mathrm{Ax}=$ axillary artery; $\mathrm{CA}=$ circulatory arrest; $\mathrm{CPB}=$ cardiopulmonary bypass; $\mathrm{CCT}=$ cross-clamp time; $\mathrm{CM}=$ cerebral malperfusion; $\mathrm{CP}=$ cerebral perfusion; $\mathrm{ER}=$ emergency room; $\mathrm{FA}=$ femoral artery; HAR = hemiarch replacement; HCA = hypothermic cardiac arrest; IA = innominate artery; LCCA Rep = left common carotid artery replacement; $\mathrm{NA}=$ not available; ONSTS time $=$ the median time from onset of neurological symptoms to surgery; $\mathrm{PAR}=$ partial arch replacement; RCCA Rep $=$ right common carotid artery replacement; $\mathrm{RCP}=$ retrograde cerebral perfusion; $\mathrm{T}=$ temperature; TAAAD = Type A acute aortic dissection; TAR = total arch replacement.

\section{REFERENCES}

Czerny M, Schoenhoff F, Etz C, Englberger L, Khaladj N, Zierer A, Weigang E, Hoffmann I, Blettner M, Carrel TP. The impact of preoperative malperfusion on outcome in acute type A aortic dissection: results from the GERAADA registry. J Am Coll Cardiol. 2015; 65(24): 2628-2635. doi: 10.1016/j.jacc.2015.04.030

Orihashi K. Cerebral malperfusion in acute aortic dissection. Surg Today. 2016; 46 (12):1353-1361. doi: 10.1007/s00595-016-1381-x

Di Eusanio M, Patel HJ, Nienaber CA, Montgomery DM, Korach A, Sundt TM, et al. Patients with type A acute aortic dissection presenting with major brain injury: should we operate on them? J Thorac Cardiovasc Surg. 2013; 145(3 Suppl): S213-21.e1. doi: 10.1016/j.jtcvs.2012.11.054.

Bossone E, Corteville DC, Harris KM, Suzuki T, Fattori R, Hutchison S, et al. Stroke and outcomes in patients with acute type A aortic dissection. Circulation. 2013; 128(11 Suppl 1): S175-9. doi: 10.1161/CIRCULATIONAHA.112.000327.

Morimoto N, Okada K, Okita Y. Lack of neurologic improvement after aortic repair for acute type A aortic dissection complicated by cerebral malperfusion: predictors and association with survival. J Thorac Cardiovasc Surg. 2011; 142(6):1540-4. doi: 10.1016/j.jtcvs.2011.05.004.

Sultan I, Bianco V, Patel HJ, Arnaoutakis GJ, Di Eusanio M, Chen EP, et al. Surgery for type A aortic dissection in patients with cerebral malperfusion: Results from the International Registry of Acute Aortic Dissection. J Thorac Cardiovasc Surg. 2021; 161(5):1713-1720.e1. doi: 10.1016/j.jtcvs.2019.11.003.

Ergin MA, Galla JD, Lansman S, Griepp RB. Acute dissections of the aorta. Current surgical treatment. Surg Clin North Am. 1985; 65(3): 721-41. doi: 10.1016/s0039-6109(16)43646-7.

Sasaki H, Harada T, Ishitoya H, Sasaki O. Aorto-carotid bypass for type A acute aortic dissection complicated with carotid artery occlusion: no touch until circulatory arrest. Interact Cardiovasc Thorac Surg. 2020; 31(2): 263-265. doi: 10.1093/icvts/ivaa092.

Estrera AL, Garami Z, Miller CC, Porat EE, Achouh PE, Dhareshwar J, Meada R, Azizzadeh A, Safi HJ. Acute type A aortic dissection complicated by stroke: can immediate repair be performed safely? J Thorac 
Cardiovasc Surg. 2006; 132(6):1404-8. doi: 10.1016/j.jtcvs.2006.07.026.

Liberati A, Altman DG, Tetzlaff J, Mulrow C, Gotzsche PC, Ioannidis JP, et al. The PRISMA statement for reporting systematic reviews and meta-analyses of studies that evaluate health care interventions: explanation and elaboration. J Clin Epidemiol. 2009; 62:e1- e34.

Higgins JP, Altman DG, Gotzsche PC, Juni P, Moher D, Oxman AD, et al. Cochrane Bias Methods Group; Cochrane Statistical Methods Group. The Cochrane Collaboration's tool for assessing risk of bias in randomised trials. BMJ. 2011; 343: d5928.

Okita Y, Okada K. Treatment strategies for malperfusion syndrome secondary to acute aortic dissection. J Card Surg. 2021; 36(5):1745-1752. doi: 10.1111/jocs.14983.

Sugiyama K, Watanuki H, Futamura Y, Okada M, Oiwa T, Makino S, Matsuyama K. Impact of direct carotid artery perfusion in acute type A aortic dissection involving the common carotid artery. Gen Thorac Cardiovasc Surg. 2021; 1-9. doi: 10.1007/s11748-021-01628-y.

Gomibuchi T, Seto T, Naito K, Chino S, Mikoshiba T, Komatsu M, Tanaka H, Ichimura H, Yamamoto T, Nakahara K, Ohashi N, Fuke M, Wada Y, Okada K. Strategies to improve outcomes for acute type A aortic dissection with cerebral malperfusion. Eur J Cardiothorac Surg. 2021; 59(3): 666-673. doi: 10.1093/ejcts/ezaa376.

31005305 Shimura S, Odagiri S, Furuya H, Okada K, Ozawa K, Nagase H, Yamaguchi M, Cho Y. Echocardiography-guided aortic cannulation by the Seldinger technique for type A dissection with cerebral malperfusion. J Thorac Cardiovasc Surg. 2020;159(3): 784-793. doi: 10.1016/j.jtcvs.2019.02.097.

Luehr M, Etz CD, Nozdrzykowski M, Lehmkuhl L, Misfeld M, Bakhtiary F, Borger MA, Mohr FW. Extraanatomic revascularization for preoperative cerebral malperfusion due to distal carotid artery occlusion in acute type A aortic dissection. Eur J Cardiothorac Surg. 2016; 49(2): 652-8. doi: 10.1093/ejcts/ezv064.

Nakamura Y, Tagusari O, Ichikawa Y, Morita A. Impact of immediate aortic repair on early and midterm neurologic status in patients with acute type a aortic dissection complicated by cerebral malperfusion. Ann Thorac Surg. 2011; 92(1): 336-8. doi: 10.1016/j.athoracsur.2010.12.065.

Tsukube T, Hayashi T, Kawahira T, Haraguchi T, Matsukawa R, Kozawa S, et al. Neurological outcomes after immediate aortic repair for acute type A aortic dissection complicated by coma. Circulation. 2011; 124: S163-7. DOI: 10.1161/CIRCULATIONAHA.110.011551

Tanaka H, Okada K, Yamashita T, Morimoto Y, Kawanishi Y, Okita Y. Surgical results of acute aortic dissection complicated with cerebral malperfusion. Ann Thorac Surg. 2005; 80(1):72-6. doi: 10.1016/j.athoracsur.2004.12.049.

Fann JI, Sarris GE, Miller DC, et al. Surgical management of acute aortic dissection complicated by stroke. Circulation. 1989; 80: 257-63.

Geirsson A, Szeto WY, Pochettino A, McGarvey ML, Keane MG, Woo YJ, Augoustides JG, Bavaria JE. Significance of malperfusion syndromes prior to contemporary surgical repair for acute type A dissection: outcomes and need for additional revascularizations. Eur J Cardiothorac Surg. 2007; 32(2):255-62. doi: 10.1016/j.ejcts.2007.04.012.

Powers WJ, Derdeyn CP, Biller J, Coffey CS, Hoh BL, Jauch EC, et al. 2015 American Heart Association/American Stroke Association focused update of the 2013 guidelines for the early management of patients with acute ischemic stroke regarding endovascular treatment. A guideline for healthcare professionals from the American Heart Association/American Stroke Association. Stroke. 2015; 46(10): 3020-35. doi: 10.1161/STR.0000000000000074.

Goldberg JB, Lansman SL, Kai M, Tang GHL, Malekan R, Spielvogel D. Malperfusion in Type A Dissection: Consider Reperfusion First. Semin Thorac Cardiovasc Surg. 2017; 29(2):181-185. doi: 
10.1053/j.semtcvs.2016.10.017.

Uchida K, Karube N, Kasama K, Minami T, Yasuda S, Goda M, Suzuki S, Imoto K, Masuda M. Early reperfusion strategy improves the outcomes of surgery for type A acute aortic dissection with malperfusion. J Thorac Cardiovasc Surg. 2018; 156(2): 483-489. doi: 10.1016/j.jtcvs.2018.02.007.

Fukuhara S, Norton EL, Chaudhary N, Burris N, Shiomi S, Kim KM, Patel HJ, Deeb GM, Yang B. Type A Aortic Dissection With Cerebral Malperfusion: New Insights. Ann Thorac Surg. 2020; S0003-4975(20)317434. doi: 10.1016/j.athoracsur.2020.08.046.

Rylski B, Urbanski PP, Siepe M, Beyersdorf F, Bachet J, Gleason TG, Bavaria JE. Operative techniques in patients with type A dissection complicated by cerebral malperfusion. Eur J Cardiothorac Surg. 2014; 46(2):156-66. doi: 10.1093/ejcts/ezu251.

Goldberg JB, Lansman SL, Kai M, Tang GHL, Malekan R, Spielvogel D. Malperfusion in Type A Dissection: Consider Reperfusion First. Semin Thorac Cardiovasc Surg. 2017; 29(2):181-185. doi: 10.1053/j.semtcvs.2016.10.017.

Uchida K, Karube N, Kasama K, Minami T, Yasuda S, Goda M, Suzuki S, Imoto K, Masuda M. Early reperfusion strategy improves the outcomes of surgery for type A acute aortic dissection with malperfusion. J Thorac Cardiovasc Surg. 2018; 156(2): 483-489. doi: 10.1016/j.jtcvs.2018.02.007.

Kreibich M, Desai ND, Bavaria JE, Szeto WY, Vallabhajosyula P, Beyersdorf F, Czerny M, Siepe M, Rylski B, Itagaki R, Okamura H, Yamaguchi A, Kimura N. Common carotid artery true lumen flow impairment in patients with type A aortic dissection. Eur J Cardiothorac Surg. 2020; ezaa322. doi: 10.1093/ejcts/ezaa322. Online ahead of print.

Shimura S, Odagiri S, Furuya H, Okada K, Ozawa K, Nagase H, Yamaguchi M, Cho Y. Echocardiographyguided aortic cannulation by the Seldinger technique for type A dissection with cerebral malperfusion. J Thorac Cardiovasc Surg. 2020; 159(3): 784-793. doi: 10.1016/j.jtcvs.2019.02.097.

Fukuda I, Imazuru T. Intentional delay of surgery for acute type A dissection with stroke. J Thorac Cardiovasc Surg. 2003;126: 290-1. doi: 10.1016/s0022-5223(03)00358-1

Cooper RJ, Schriger DL. How accurate is a CT scan in identifying acute strokes? West J Med. 1999; 171(5-6): 356-7.

\section{Hosted file}

Figure 1. .docx available at https://authorea.com/users/446281/articles/545575-surgicaltreatment-of-type-a-acute-aortic-dissection-with-cerebral-malperfusion-a-systematicreview

\section{Hosted file}

Figure 2..docx available at https://authorea.com/users/446281/articles/545575-surgicaltreatment-of-type-a-acute-aortic-dissection-with-cerebral-malperfusion-a-systematicreview 